\title{
NOTE
}

\section{Evaluation of a Rapid Competitive Protein Binding Assay for Progesterone in Pregnancy and some of its Complications}

\author{
ENG SoON TEOH* AND N. P. DAS** \\ * Department of Obstetrics and Gynaecology, University of Singapore, \\ Kandang Kerbau Hospital, Singapore 8 and \\ **Department of Biochemistry, Faculty of Medicine, \\ University of Singapore, Singapore, 3
}

\begin{abstract}
Synopsis
The assay of serum progesterone using the competitive protein binding procedure allows rapid and precise measurements of progesterone and makes large population studies on various complications of pregnancy more feasible. Several important factors were found to influence the accuracy and reproducibility of the assay. The levels of serum progesterone in some normal pregnancy, hydatidiform mole and choriocarcinoma are presented.
\end{abstract}

Several publications have described the assay of serum and plasma progesterone (Szarka, 1940; Short, 1958; Greig et al., 1962; Neil et al., 1967; Weist, 1967; Yannone, 1968; Johansson, 1969; Rubin et al., 1970; Murphy, 1971). Clinical and research applications for plasma progesterone determinations have been suggested (Johansson, 1969). However, the methods described involved slow and laborious techniques. It was desirable for us to investigate a method involving competitive protein binding (CPB) for progesterone assay which would be simple and rapid. Thus, the CPB method of Neill et al. (1967) was analysed to study the important factors that would influence the accurate determination of progesterone and also simplify the procedure to enable rapid assay of large number of samples.

\section{Materials and Methods}

\section{Reagents}

All reagents were used without further purifica-

Received for publication March 12, 1973.

Address for reprint: ENG SOON TEOH, M.D., Department of Obstetrics and Gynaecology, University of Singapore, Kandang Kerbau Hospital, Singapore, 8. tion. Florisil (Sigma Chemical Co., St. Louis, U.S.A.) was washed four times with water and activated by heating at $130^{\circ} \mathrm{C}$. Activated Florisil was usable for at least two months.

Plasma from female volunteers after 14 days treatment with ethinyl oestradiol $(50 \mu \mathrm{g} /$ day $)$ was used as the source of corticosterone binding globulin (CBG).

\section{Extraction and Separation}

Pregnancy serum $(0.1 \mathrm{~m} l)$ was extracted with 10 volumes $(1 \mathrm{~m} l)$ of petroleum ether. The extract was eluted on a $25 \times 1 \mathrm{~cm}$ Sephadex LH-20 column using the chloroform-heptane-ethanol mixture of Murphy $(200: 200: 1, \mathrm{v} / \mathrm{v} / \mathrm{v})$ (Murphy, 1971). Progesterone is found in the 3-13 m/ eluates, $20 \alpha$-hydroxyprogesterone is in the $13-32 \mathrm{ml}$ eluates and $17 \alpha$-hydroxyprogesterone from $20-50 \mathrm{~m} l$ of the eluates.

\section{Standard Curve}

A range of $0,0.5,1,2,5,10$ and $20 \mathrm{ng}$ progesterone in $50 \mu l$ of ethanol in $3 \mathrm{~m} /$ test-tubes was evaporated to dryness. ${ }^{3} \mathrm{H}$-corticosterone-CBG mixture $(1 \mathrm{ml})$ containing $27-32 \mathrm{ng}{ }^{3} \mathrm{H}$-corticosterone and $100 \mu \mathrm{l}$ CBG plasma in $100 \mathrm{~m} l$ water was added to each tube and incubated at $45^{\circ} \mathrm{C}$ for $5 \mathrm{~min}$ to facilitate the progesterone into solution. After shaking on a vortex mixer, the tubes were incubated in an ice bath for 30 min to facilitate binding by CBG. With the tubes still in the ice bath, $40 \mathrm{mg}$ activated Florisil was added to the first tube which was then shaken on a vortex mixer for exactly 30 seconds. The tube was returned to the ice bath. The process was repeated until all the tubes had been treated with Florisil. Then $0.5 \mathrm{~m} l$ 
of the supernatant was transferred into a polyethylene counting vial and $5 \mathrm{~m} l$ of scintillation fluid added. The samples were counted with a Packard Tri-Carb model 3320-01 liquid scintillation spectrometer for $10 \mathrm{~min}$.

\section{Subjects}

Blood was collected in the morning from 206 normal pregnant patients at various stages of gestation. Five serum specimens at different trimesters were extracted and chromatographed as described above and $1 \mathrm{~m} l$ eluants were assayed against a progesterone standard. Thereafter, all 206 sera were extracted with the same batch of petroleum ether and assayed directly without subjection to prior column separation.

\section{Results}

\section{Sensityvity, Specificity and Accuracy}

The typical standard curve under the conditions of the assay procedures is presented in Figure 1. It has a working range of 0.5 to $10 \mathrm{ng} / \mathrm{m} l$. Although $0.1 \mathrm{ng} / \mathrm{m} l$ could be dis- tinguished from $0 \mathrm{ng} / \mathrm{ml}$, for the purpose of assaying pregnancy samples the 0.1 to 0.5 $\mathrm{ng} / \mathrm{m} l$ range was not required.

CBG binds a wide variety of steroids and displacement curves produced by testosterone, $20 \alpha$-hydroxyprogesterone, 17 $\alpha$-hydroxyprogesterone and corticosterone are shown in Figure 1. This allows the competitive protein binding method to be modified to measure other steroids simply by a selective choice of solvents for extraction.

The standard elution patterns of the petroleum ether extracts of $0.5 \mathrm{ml}$ of first and third trimester pregnancy sera are shown in Figure 2. More than $85 \%$ of the extracted steroid is progesterone, whilst $20 \alpha$-hydroxyprogesterone and $17 \alpha$-hydroxyprogesterone together accounted for less than $15 \%$.

Recovery of ${ }^{3} \mathrm{H}-7$-progesterone added to 12 samples of male serum ranging from 1 to $100 \mathrm{ng} / \mathrm{m} l$ was found to be $75.9 \pm 3.5 \%$. To

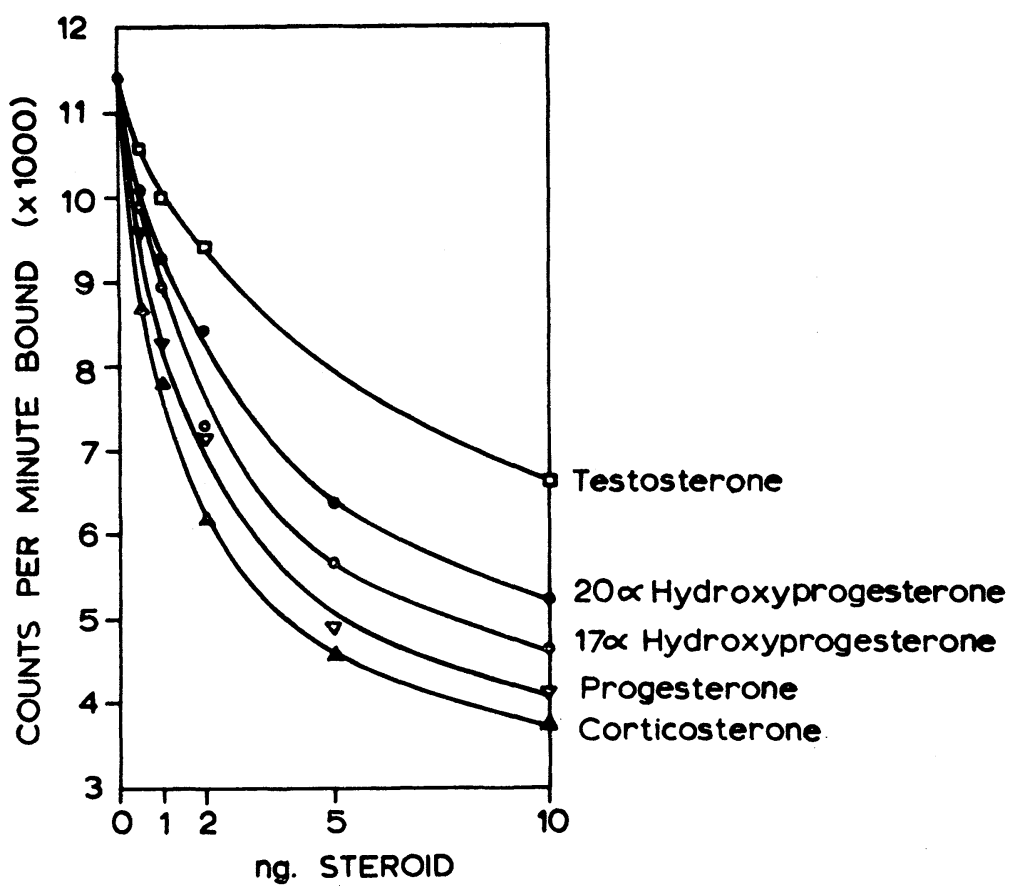

Fig. 1. Standard Curve for Progesterone Assay. Only values within the 0.5-10 ng range are read. Note the displacement curves of ${ }^{3} \mathrm{H}$-corticosterone-CBG system produced by testosterone, $20 \alpha$-hydroxyprogesterone, $17 \alpha$-hydroxyprogesterone and corticosterone. 


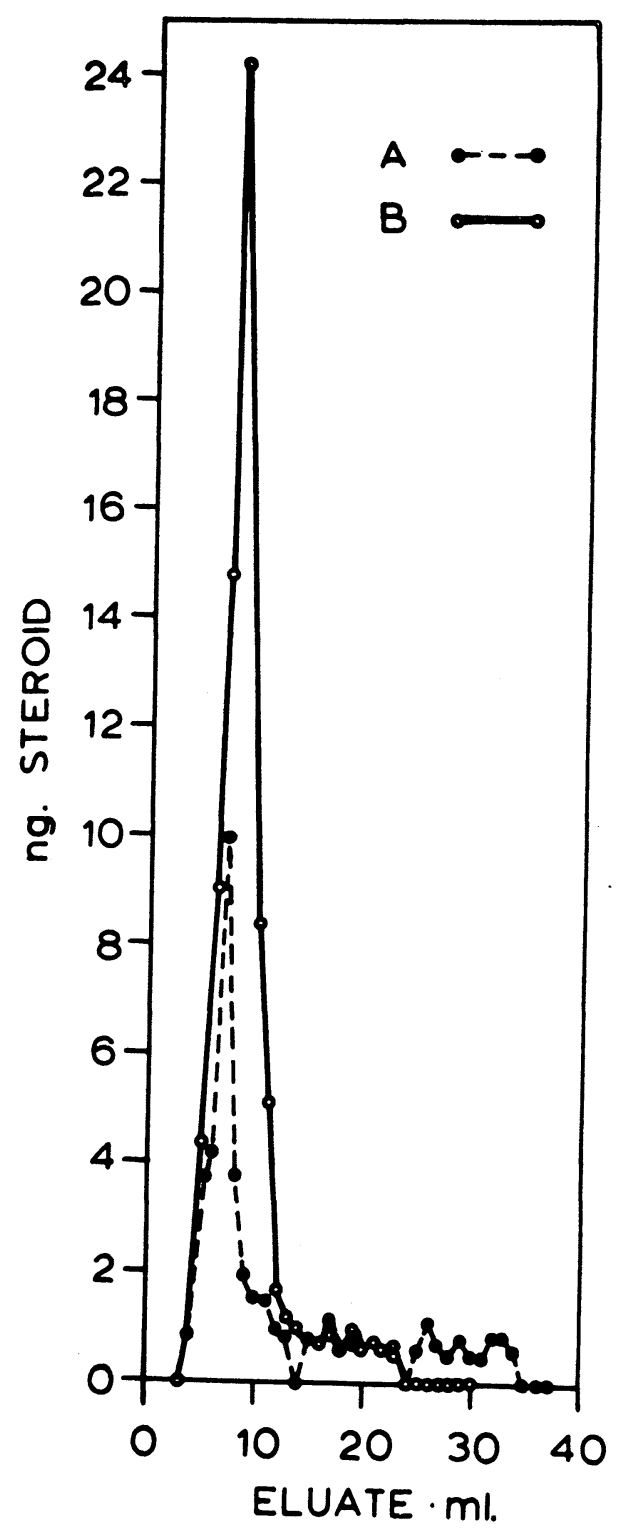

Fig. 2. Steroid fractions from petroleum ether extracts of $0.5 \mathrm{~m} /$ of a first trimester (10th week) pregnancy serum (A) and a third trimester serum (B). The major peaks are progesterone and the minor peaks are 20a-hydroxyprogesterone. There is a small amount of $17 \alpha$-hydroxyprogesterone in the first trimester.

exclude possible error which may result from quenching, ether extracts of $0.1 \mathrm{~m} l$ male serum was added to the standard tubes and dried off before the addition of the scintillation fluid. All figures were corrected for extraction loss. Throughout the study, approximately $90 \%$ of the tested samples gave duplicates which were within $\pm 10 \%$ of their mean values. The remainder were reassayed.

\section{Effect of Incubation Time}

Standard curves performed with 10, 20, 40 and $60 \mathrm{~min}$ incubation in the ice bath showed no significant alteration to the sensitivity of the assay. There was also no significant increase in binding of ${ }^{3} \mathrm{H}$-corticosterone to $\mathrm{CBG}$ when the incubation time was prolonged beyond $20 \mathrm{~min}$.

Effect of Incubaion Temperature on the Standard Curve

To maintain the incubation temperature evenly at $4{ }^{\circ} \mathrm{C}$ throughout the assay the tubes were immersed in the ice shavings to a depth of $5 \mathrm{~cm}$. When the temperature was not properly maintained at $4^{\circ} \mathrm{C}$, the standard curve was severely flattened (Fig. 3).

\section{Florisil Contact Time}

The percentage of ${ }^{3} \mathrm{H}$-corticosterone-CBG removed by activated Florisil increased directly when the mixing time was increased (Fig. 4). Reproducibility was achieved by observing an exact 30 second contact time with Florisil for every tube in the assays.

\section{Serum Progesterone in Normal Pregnancy,} Hydatidiform Mole and Choriocarcinoma

The serum progesterone concentrations of random single samples collected from 250 pregnant Asian patients is shown in Table 1. In the first trimester the mean value of 19.1 $\mathrm{ng} / \mathrm{m} /$ was only slightly higher than the level during the luteal phase of the menstrual cycle. It increased markedly to $60.4 \mathrm{ng} / \mathrm{m} /$ in the mid trimester and $135.3 \mathrm{ng} / \mathrm{ml}$ in the last trimester. At term, mean serum progesterone was $156.9 \mathrm{ng} / \mathrm{m} /$. There is a wide difference between the lowest and highest values for serum progesterone all throughout pregnancy. 


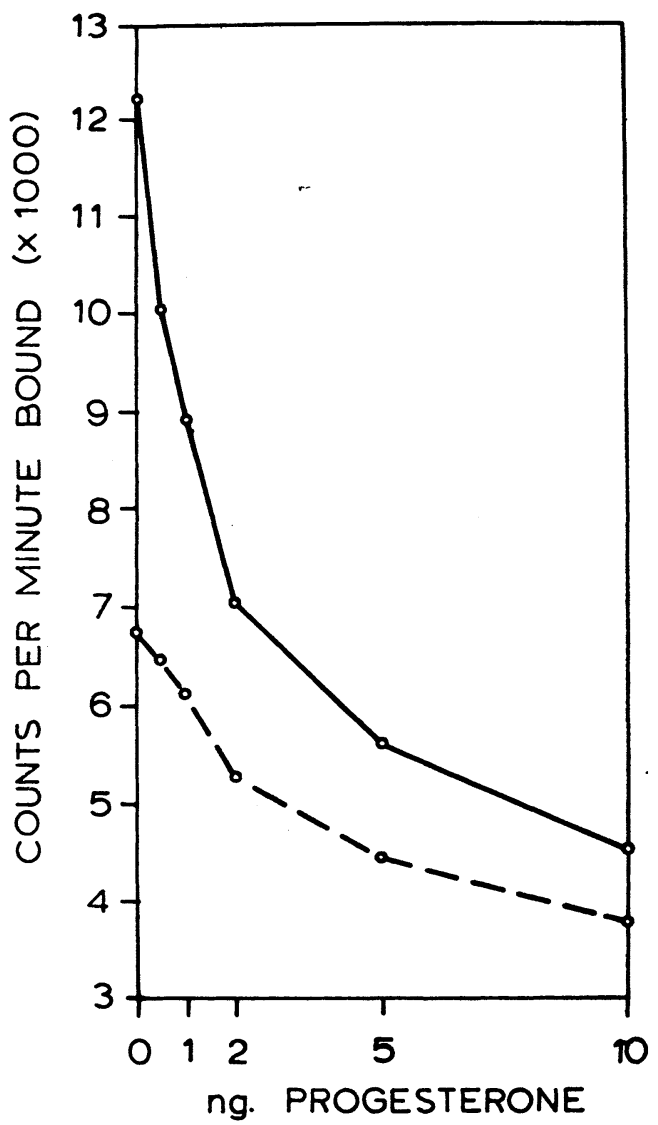

Fig. 3. Effect of incubation temperature on the standard curve. Continuous line shows standard curve with the tubes properly immersed in ice shavings. Broken line represents a standard curve in an experiment where the tubes were seated in a styrofoam box with ice cubes and the temperature was not properly maintained.

In 21 cases of hydatidiform mole, mean serum progesterone was $106.0 \mathrm{ng} / \mathrm{ml}$ which is in the range of levels normally encountered in the last trimester. However, the duration of amenorrhoea was generally between the 10 th to 22 nd week. Hence, mole patients showed elevated serum progesterone. In 10 cases of choriocarcinoma, the mean serum progesterone was $16.9 \mathrm{ng} / \mathrm{ml}$. The range of values corresponded to those in the first trimester.

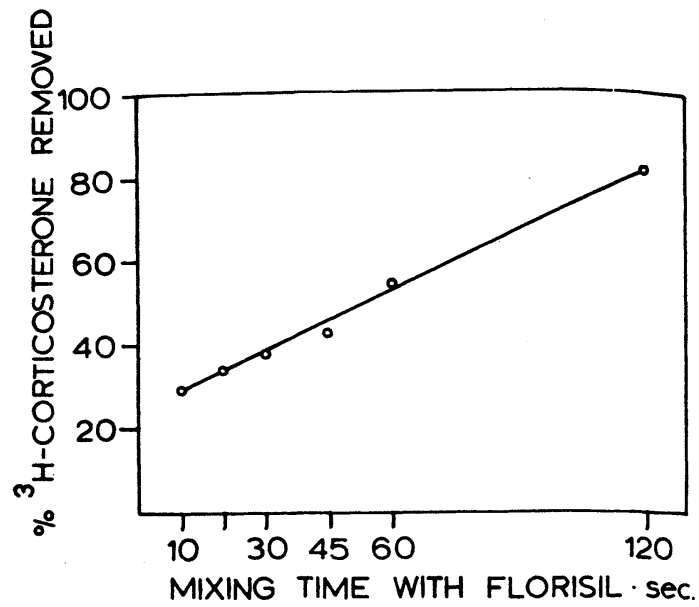

Fig. 4. Percentage of ${ }^{3} \mathrm{H}$-corticosterone-CBG removed by Florisil with various mixing times.

Table 1. Serum progesterone in normal pregnancy, hydatidiform mole and choriocarcinoma

\begin{tabular}{ccrc}
\hline & $\begin{array}{l}\text { No. of } \\
\text { Samples }\end{array}$ & $\begin{array}{c}\text { Mean } \\
(\mathrm{ng} / \mathrm{m} l)\end{array}$ & \multicolumn{1}{l}{$\begin{array}{l}\mathrm{Range} \\
(\mathrm{ng} / \mathrm{m} l)\end{array}$} \\
\hline Normal Pregnancy & & & \\
1st Trimester & 87 & 19.1 & $3.3-51.3$ \\
2nd Trimester & 39 & 60.4 & $17.4-115$ \\
3rd Trimester & 80 & 135.3 & $39.5-334$ \\
Hydatidiform Mole & 21 & 106.0 & $17.8-263$ \\
Choriocarcinoma & 10 & 16.9 & $1.3-61$ \\
\hline
\end{tabular}

\section{Discussion}

The competitive protein binding method is very simple to carry out and can be rapidly repeated in any laboratory. The important factors to note in the method are a strict temperature control and an exact contact period with Florisil. The petroleum ether lot should be carefully selected and the Florisil must be washed several times, activated and maintained in a dry state.

The values of serum progesterone in this study are similar to the plasma values reported by Johansson using a similar method (Johansson, 1969), and are comparable to the values obtained by gas liquid chromatography (Yannone, 1968) and the double isotope 
derivative assay (Weist, 1967). The results also correspond to the findings of earlier workers who employed a chemical method (Short, 1958; Greig et al., 1962).

The CPB method has the advantage of simplicity, sensitivity, speed and economy. In our laboratory, a single technician handles 50 to 100 samples per week. The original bioassay methods had a low accuracy, required large numbers of laboratory animals and the results were only available after $44 \mathrm{hr}$. The chemical method required a large blood sample of $40 \mathrm{ml}$ (Short, 1958) and both gas liquid chromatography and double isotope derivative assay are difficult to perform. An advantage of the present technique is the exclusion of the chromatographic step which was made possible by the choice of suitable petroleum ether solvent. By running chromatograms on the petroleum ether extracts, it is possible to select petroleum ether lots which will selectively extract progesterone without carrying over appreciable amounts of $20 \alpha$-hydroxyprogesterone and $17 \alpha$-hydroxyprogesterone. However, during pregnancy, progesterone is the principle progestogen present in the circulation. 20 $\alpha$-hydroxyprogesterone present in low concentration in the plasma has a low affinity for CBG and runs parallel to progesterone throughout pregnancy and therefore does not appreciably affect the serum progesterone value (Greig et al., 1962; Rubin et al., 1970).

In hydatidiform mole, ovarian theca lutein cysts secrete appreciable quantities of $20 \alpha-$ hydroxyprogesterone and 17 $\alpha$-hydroxyprogesterone (Teoh et al.). Elution of petroleum ether extracts of sera from such patients showed that the two hydroxyprogesterones taken to- gether accounted for approximately $15 \%$ of the serum "progesterone" measured on an uneluted petroleum ether extract. For clinical purposes, this may probably be ignored when a rapid result is required.

\section{Acknowledgment}

The authors are grateful to Miss W. P. Chow and Mr. A. Ambrose for skillful technical assistance, to Professor S. S. Ratnam for his support and to Dr. J. Coghlan of the Howard Florey Institute of Experimental Physiology, Sydney, Australia, for generous donation of some labelled steroids. The study was supported in part by China Medical Board Grant No. 66-871.

\section{References}

Greig, M., M. G. Coyle, W. Cooper and J. Walker (1962). J. Obstet. Gynaec. Brit. Comm. 69, 772.

Johansson, E. D. B. (1969). Acta endocrinol. $(K h b) .61,607$.

Murphy, B. E. P. In "Steriod Assay by Protein Binding”, ed. E. Diczfalusy, Copenhagen, Bogtrykkeriet Forum 1971.

Neill, J. D., E. D. B. Johansson, J. K. Datta and E. Knobil (1967). J. Clin. Endocr. 27, 1167.

Rubin, B. L., M. Maralit and J. H. Kinaro (1970). Ibid. 31, 511.

Short, R. V. (1958). J. Endocrinol. 16, 415.

Szarka, A. J. (1940). J. Endocrinol. 2, 1.

Teoh, E. S., N. P. Das, M. Y. Dawood and S. S. Ratnan. Proceedings of the 5 th Singapore-Malaysia Congress of Medicine.

Weist, W. G. (1967). Steroids 10, 279.

Yannone, M. E. (1968). Amer. J. Obstet. Gynaec. 101, 1054. 